\title{
N-Terminal Pro-Brain Natriuretic Peptide Plasma Levels Are Associated with Intermediate-Term Follow-Up Cancer in Coronary Patients
}

\author{
José Tuñón 1,2,3,4,*i), Ana Pello 1,2 , Álvaro Aceña ${ }^{1,2}$, Sergio Ramos-Cillán ${ }^{2}$, Juan Martínez-Milla 1,2, \\ Óscar González-Lorenzo ${ }^{1,2}{ }^{\mathbb{D}}$, Jesús Fuentes-Antras ${ }^{5}$, Nieves Tarín ${ }^{6}$, Carmen Cristóbal ${ }^{7,8}$, \\ Luis M. Blanco-Colio ${ }^{3,4}{ }^{(0}$, José Luis Martín-Ventura ${ }^{2,3,4}$, Ana Huelmos ${ }^{9}$, Carlos Gutiérrez-Landaluce ${ }^{7}(\mathbb{D}$, \\ Marta López-Castillo ${ }^{1,2}$, Joaquín Alonso ${ }^{8,10}$, Lorenzo López Bescós ${ }^{8}$, Jesús Egido ${ }^{2,3,11}$, \\ Ignacio Mahíllo-Fernández ${ }^{12}$ (1) and Óscar Lorenzo ${ }^{2,3,11}$ (1)
}

check for updates

Citation: Tuñón, J.; Pello, A.; Aceña,

Á.; Ramos-Cillán, S.; Martínez-Milla,

J.; González-Lorenzo, Ó.;

Fuentes-Antras, J.; Tarín, N.;

Cristóbal, C.; Blanco-Colio, L.M.; et al.

N-Terminal Pro-Brain Natriuretic

Peptide Plasma Levels Are

Associated with Intermediate-Term

Follow-Up Cancer in Coronary

Patients. J. Clin. Med. 2021, 10, 4042.

https://doi.org/10.3390/jcm10184042

Academic Editors: Tim A. Fischell and Taishi Yonetsu

Received: 14 August 2021

Accepted: 3 September 2021

Published: 7 September 2021

Publisher's Note: MDPI stays neutral with regard to jurisdictional claims in published maps and institutional affiliations.

Copyright: (c) 2021 by the authors. Licensee MDPI, Basel, Switzerland. This article is an open access article distributed under the terms and conditions of the Creative Commons Attribution (CC BY) license (https:/ / creativecommons.org/licenses/by/ $4.0 /)$.
1 Department of Cardiology, IIS-Fundación Jiménez Díaz, 28040 Madrid, Spain; ampello@fjd.es (A.P.); aacena@fjd.es (Á.A.); juan.mmilla@fjd.es (J.M.-M.); ogonzalez@quironsalud.es (Ó.G.-L.); marta.lcastillo@fjd.es (M.L.-C.)

2 Department of Medicine, School of Medicine, Autónoma University, 28040 Madrid, Spain; sergio.ramosc@quironsalud.es (S.R.-C.); jlmartin@fjd.es (J.L.M.-V.); jegido@fjd.es (J.E.); olorenzo@fjd.es (Ó.L.)

3 Laboratory of Vascular Pathology, IIS-Fundación Jiménez Díaz, 28040 Madrid, Spain; lblanco@fjd.es

4 CIBERCV, 28040 Madrid, Spain

5 Department of Oncology, Hospital Clínico Universitario San Carlos, 28040 Madrid, Spain; jfuentesantras@outlook.com

6 Department of Cardiology, Hospital Universitario de Móstoles, 28040 Madrid, Spain; nieves.tarin@salud.madrid.org

7 Department of Cardiology, Hospital de Fuenlabrada, 28040 Madrid, Spain; carmen.cristobal@salud.madrid.org (C.C.); cgutierrezl@salud.madrid.org (C.G.-L.)

8 Department of Medicine, School of Medicine, Rey Juan Carlos University, Alcorcón, 28040 Madrid, Spain; joaquinjalonso@gmail.com (J.A.); 1lbescos@secardiologia.es (L.L.B.)

9 Department of Cardiology, Hospital Universitario Fundación Alcorcón, 28040 Madrid, Spain; ahuelmos@yahoo.es

10 Department of Cardiology, Hospital de Getafe, 28040 Madrid, Spain

11 CIBERDEM, 28040 Madrid, Spain

12 Research Unit, IIS-Fundación Jiménez Díaz, 28040 Madrid, Spain; imahillo@fjd.es

* Correspondence: jtunon@fjd.es

Abstract: N-terminal pro-brain natriuretic peptide (NT-proBNP) plasma levels are increased in patients with cancer. In this paper, we test whether NT-proBNP may identify patients who are going to receive a future cancer diagnosis (CD) in the intermediate-term follow-up. We studied 962 patients with stable coronary artery disease and free of cancer and heart failure at baseline. This sample represents a re-analysis of a previous work expanding the sample size and the follow-up. NT-proBNP, galectin-3, monocyte chemoattractant protein-1, high-sensitivity C-reactive protein, high-sensitivity cardiac troponin I (hsTnI), and calcidiol (vitamin D) plasma levels were assessed. The primary outcome was new CD. After 5.40 (2.81-6.94) years of follow-up, 59 patients received a CD. NT-proBNP [HR 1.036 CI (1.015-1.056) per increase in $100 \mathrm{pg} / \mathrm{mL} ; p=0.001$ ], previous atrial fibrillation (HR $3.140 \mathrm{CI}(1.196-8.243) ; p=0.020)$, and absence of previous heart failure (HR 0.067 CI (0.006-0.802); $p=0.033$ ) were independent predictors of receiving a CD in the first three years of follow-up. None of the variables analyzed predicted a CD beyond this time. The number of patients developing heart failure during follow-up was $0(0.0 \%)$ in patients receiving CD in the first three years of follow-up, $2(6.9 \%)$ in those receiving a CD diagnosis beyond this time, and $40(4.4 \%)$ in patients not developing cancer $(p=0.216)$. These numbers suggest that future heart failure was not a confounding factor. In patients with coronary artery disease, NT-proBNP was an independent predictor of $\mathrm{CD}$ in the first three years of follow-up but not later, suggesting that it could be detecting subclinical undiagnosed cancers. 
Keywords: coronary artery disease; N-terminal pro-brain natriuretic peptide; cancer; tumor; biomarker

\section{Introduction}

Patients with coronary artery disease (CAD) are at risk of developing malignancies, given that cancer shares some risk factors with this disorder, such as age, smoking, and even some dietary patterns [1-3]. Thus, finding biomarkers that predict both the risk of cancer and of cardiovascular events could be useful in CAD patients.

Natriuretic peptides are secreted by cancer cells $[4,5]$ and N-terminal fragments of pro-brain natriuretic peptide (NT-proBNP) levels are increased in patients with cancer [6]. Previously we have reported that NT-proBNP plasma levels predict a future diagnosis of cancer in 704 patients with CAD from Biomarkers in Acute Coronary Syndrome \& Biomarkers in Acute Myocardial Infarction (BACS \& BAMI) studies [7]. We launched the hypothesis that NT-proBNP could be merely detecting subclinical cancers rather than being a real predictor.

In the present work, we present a re-analysis of patients from BACS \& BAMI studies, expanding the sample size and follow-up, and studying 962 patients with CAD free of malignancies at baseline.

In this paper, we test the hypothesis that NT-proBNP plasma levels predict a new cancer diagnosis (CD) only in the intermediate-term follow-up but not in the long-run. Along with NT-proBNP, we also tested these biomarkers: monocyte chemoattractant protein-1 (MCP-1), involved in inflammation and atherothrombosis, among other processes [8,9]: galectin-3, related to malignancies, heart failure, thrombosis, and renal dysfunction $[10,11]$; high-sensitivity cardiac troponin I (hsTnI), which has been described to have prognostic value in stable CAD [12]; and vitamin D (calcidiol) plasma levels, as low levels of this molecule were related to cancer [13]. High-sensitivity C-reactive protein (hsCRP) was studied as a reference, given the large amount of information published on this biomarker on cardiovascular disease.

\section{Materials and Methods}

\subsection{Patients}

Nine-hundred and sixty-eight patients with stable CAD, who had suffered acute coronary syndrome between six and twelve months before were included in this study. These patients were part of the BACS \& BAMI (Biomarkers in Acute Coronary Syndrome \& Biomarkers in Acute Myocardial Infarction) studies, carried out in five hospitals in Madrid. Inclusion and exclusion criteria were defined previously [14].

The research protocol conforms to the ethical guidelines of the 1975 Declaration of Helsinky as reflected in a priori approval by the human research committees of the institutions participating in this study: Fundación Jiménez Díaz, Hospital Fundación Alcorcón, Hospital de Fuenlabrada, Hospital Universitario Puerta de Hierro Majadahonda, and Hospital Universitario de Móstoles. All patients signed informed consent documents. Patients and public were not involved in the design of this study.

\subsection{Study Design}

At baseline, clinical variables were recorded, and twelve-hour fasting venous blood samples were withdrawn and collected in EDTA. Blood samples were centrifuged at $2500 \times g$ for $10 \mathrm{~min}$ and plasma was stored at $-80^{\circ} \mathrm{C}$. Patients were seen every year at their hospital. At the end of follow-up, the medical records were reviewed, and patient status was confirmed by telephone contact. Plasma extraction and baseline visits took place between January 2007 and December 2014. The last follow-up visits were carried out in June 2016.

The primary outcome was the development of a new cancer with histological confirmation, excluding non-melanocytic skin tumors. 


\subsection{Analytical Studies}

Blood samples were collected in ethylene-diamine-tetra-acetic acid and centrifuged at $2500 \times g$ for $10 \mathrm{~min}$ and plasma was stored at $-80^{\circ} \mathrm{C}$. Patients were seen every year at their hospital.

The investigators who performed the laboratory determinations were unaware of the clinical data. Plasma concentrations of MCP-1 and galectin-3 were determined in duplicate using commercially available enzyme-linked immunosorbent assay kits (DCP00, R\&D Systems and BMS279/2 Bender MedSystems, respectively) following the manufacters' instructions. HsCRP was assessed by latex-enhanced immunoturbidimetry (ADVIA 2400 Chemistry System, Siemens, Munich, Germany), NT-proBNP by immunoassay (VITROS, Orthoclinical Diagnostics, Raritan, NJ, USA), and hsTnI was assessed by direct quimioluminiscence (ADVIA Centaur, Siemens, Munich, Germany). Plasma calcidiol levels were quantified by chemiluminescent immunoassay (CLIA) on the LIAISON XL analyzer (LIAISON 25OH-Vitamin D total Assay DiaSorin, Saluggia, Italy). Lipids, glucose, and creatinin were determined by standard methods (ADVIA 2400 Chemistry System, Siemens, Germany).

\subsection{Statistical Analysis}

Quantitative data following a normal distribution are displayed as mean \pm standard deviation and compared using the Student $t$-test and the ANOVA (analysis of variance) for two and three comparisons, respectively. Quantitative data not following a normal distribution are displayed as median (interquartile range) and compared using the Mann-Whitney and the Kruskal-Wallis tests for two and three comparisons, respectively. Qualitative variables are displayed as percentages and compared by $\chi^{2}$ or the Fisher exact test when appropriate. Univariate Cox regression analysis was used to study the predictive power of the variables studied. Multivariate Cox regression analysis was performed including all variables showing $p<0.20$ at univariate analysis.

Analyses were performed with R v3.5.1 ( $R$ foundation for Statistical Computing, Viena, Austria) and SPSS 19.0 (SPSS Inc., New York, NY, USA). Statistical significance was set at $p<0.05$ (two-tailed).

\section{Results}

\subsection{Population of the Study}

We included 968 patients with stable CAD. However, five patients were lost to followup, and one patient died, and the cause of death could not be confirmed. Thus, he was also considered as lost to follow-up, leaving 962 patients for the analysis, who were followed for an average period of $5.40(2.81-6.94)$ years.

Of the 962 patients studied, 59 developed cancer during follow-up. We divided the sample into three subgroups: patients who did not develop cancer during follow-up $(n=903)$, those receiving a CD in the first 3 years of follow-up $(n=30)$, and patients receiving a $C D$ beyond 3 years $(n=29)$. We used the three-year cutt-off as it divided the sample in a similar number of patients receiving a CD before and beyond this point. Overall, baseline variables were well balanced among the three subgroups of patients, and the only significant differences observed were: more incidence of previous heart failure in patients not receiving a $\mathrm{CD}$ during follow-up, higher hsCRP levels in those receiving a CD in the first three years of follow-up, and fewer patients receiving P2Y12 inhibitors in the group receiving a CD beyond three years of follow-up (Table 1). There were no significant differences in in the presence of left-systolic ventricular dysfunction, diabetes or hypertension, among others. 
Table 1. Baseline characteristics of the patients.

\begin{tabular}{|c|c|c|c|c|}
\hline Characteristic & $\begin{array}{l}\text { Patients without } \\
\text { Cancer } \\
(n=903)\end{array}$ & $\begin{array}{l}\text { Patients with Cancer } \\
\text { in } 3 \text { Years } \\
(n=30)\end{array}$ & $\begin{array}{l}\text { Patients with Cancer } \\
\text { beyond } 3 \text { Years } \\
(n=29)\end{array}$ & $p$ Value \\
\hline Age $(y r)$ & $61.1 \pm 12.0$ & $66.0 \pm 11.6$ & $62.2 \pm 12.3$ & 0.083 \\
\hline Male sex (\%) & 23.5 & 30.0 & 27.6 & 0.632 \\
\hline Body-mass index $\left(\mathrm{Kg} / \mathrm{m}^{2}\right)$ & $28.5 \pm 4.35$ & $27.8 \pm 4.71$ & $28.8 \pm 3.78$ & 0.621 \\
\hline Diabetes (\%) & 24.0 & 16.7 & 31.0 & 0.434 \\
\hline Present smoker $(\%)$ & 14.0 & 13.3 & 10.3 & 0.955 \\
\hline Present or past smoker (\%) & 75.6 & 86.7 & 75.9 & 0.380 \\
\hline Hypertension $(\%)$ & 63.5 & 80.0 & 72.4 & 0.115 \\
\hline Previous heart failure (\%) & 12.3 & 3.3 & 0.0 & 0.036 \\
\hline Peripheral artery disease (\%) & 3.8 & 3.3 & 3.4 & 1.000 \\
\hline Cerebrovascular events (\%) & 2.9 & 0.0 & 3.4 & 0.660 \\
\hline Ejection fraction $<40 \%(\%)$ & 6.9 & 6.9 & 10.7 & 0.585 \\
\hline Present or past atrial fibrillation (\%) & 6.0 & 16.7 & 6.9 & 0.064 \\
\hline \multicolumn{5}{|l|}{ Medical therapy } \\
\hline Acetylsalicylic acid (\%) & 92.6 & 96.7 & 89.7 & 0.556 \\
\hline AntiP2Y12 (\%) & 75.7 & 76.7 & 51.7 & 0.013 \\
\hline Acenocumarol (\%) & 5.2 & 3.3 & 3.4 & 1.000 \\
\hline Statins (\%) & 94.5 & 93.3 & 93.1 & 0.567 \\
\hline Oral antidiabetic drugs (\%) & 16.9 & 10.0 & 24.1 & 0.351 \\
\hline Insulin $(\%)$ & 7.0 & 0.0 & 0.0 & 0.150 \\
\hline ACEI $(\%)$ & 62.5 & 63.3 & 44.8 & 0.155 \\
\hline Angiotensin receptor blockers (\%) & 15.0 & 13.3 & 24.1 & 0.370 \\
\hline Aldosterone receptor blockers (\%) & 7.0 & 6.7 & 3.4 & 0.919 \\
\hline Betablockers (\%) & 78.8 & 73.3 & 65.5 & 0.184 \\
\hline Diuretics (\%) & 18.8 & 23.3 & 27.6 & 0.422 \\
\hline Amiodarone & 0.9 & 0.0 & 0.0 & 1.000 \\
\hline Digoxine & 0.3 & 0.0 & 0.0 & 1.000 \\
\hline \multicolumn{5}{|l|}{ ANALYTICAL DATA } \\
\hline LDL cholesterol (mg/dL) & $80.5 \pm 25.0$ & $78.1 \pm 25.2$ & $85.3 \pm 22.5$ & 0.518 \\
\hline HDL cholesterol (mg/dL) & $42.0 \pm 10.8$ & $43.4 \pm 10.7$ & $44.5 \pm 13.6$ & 0.397 \\
\hline Non-HDL cholesterol & $104 \pm 30.5$ & $98.4 \pm 27.1$ & $111 \pm 28.2$ & 0.291 \\
\hline Triglycerides (mg/dL) & $101(66.0)$ & $92.5(66.2)$ & $121(56.0)$ & 0.135 \\
\hline Glycemia (mg/dL) & $101(24.0)$ & $98.0(17.8)$ & $99.0(19.0)$ & 0.792 \\
\hline $\left.\mathrm{m}^{2}\right)$ eGFR (CKD-EPI) (ml/min $/ 1.73$ & $78.6 \pm 19.4$ & $74.4 \pm 19.2$ & $73.1 \pm 17.8$ & 0.171 \\
\hline Hs C-reactive protein (mg/L) & $1.08(2.72)$ & $2.68(4.63)$ & $1.49(2.81)$ & 0.004 \\
\hline NT-ProBNP (pg/mL) & $176(297)$ & $272(815)$ & $155(217)$ & 0.324 \\
\hline $\mathrm{MCP}-1(\mathrm{pg} / \mathrm{mL})$ & $135(74)$ & $151(58)$ & $133(43)$ & 0.725 \\
\hline Galectin-3 (ng/mL) & $7.86(3.89)$ & $7.85(4.13)$ & $7.50(2.89)$ & 0.253 \\
\hline Hs troponin $\mathrm{I}(\mathrm{ng} / \mathrm{mL})$ & $0.003(0.010)$ & $0.002(0.016)$ & $0.003(0.009)$ & 0.837 \\
\hline Calcidiol (ng/mL) & $20.4 \pm 8.55$ & $21.4 \pm 9.8$ & $17.6 \pm 6.93$ & 0.175 \\
\hline
\end{tabular}

Values are presented as mean \pm standard deviation and median (interquartile range). ACEI: angiotensin-converting inhibitors; CKD-EPI: chronic kidney disease epidemiology collaboration equation; eGFR: estimated glomerular filtration rate; HDL: high-density lipoprotein; Hs: high-sensitivity; LDL: low-density lipoprotein MCP-1: monocyte chemoattractant protein-1; NT-Pro-BNP: N-terminal pro-Brain natriuretic peptide. 
In the group of patients receiving a $\mathrm{CD}$ in the first three years, the median time to CD was $1.53(0.50-2.35)$ years. In this group, there were $15(50.0 \%)$ carcinomas, $11(36.7 \%)$ adenocarcinomas, $3(10.0 \%)$ cancers with other histology, and $1(3.3 \%)$ case of unknown etiology. Among patients receiving a $\mathrm{CD}$ beyond this time the median time to a $\mathrm{CD}$ was $4.98(3.12-9.28)$ years. In this group, there were $13(44.8 \%)$ carcinomas, $11(37.9 \%)$ adenocarcinomas, $5(17.2 \%)$ cancers with other histology, and $0(0.0 \%)$ cancers of unknown histology. The case of unknown histology corresponded to an 83-year-old man with images clearly compatible with lung cancer with metastases, who was dying, and the doctors decided not to perform histological analysis. Table 2 shows the locations of the cancers.

Table 2. Location of the cancers diagnosed during follow-up.

\begin{tabular}{lll}
\hline Cancer Location & Cancer $<3$ Years & Cancer $>3$ Years \\
\hline Prostate & $5(16.7 \%)$ & $6(20.7 \%)$ \\
Liposarcoma & $1(3.3 \%)$ & $0(0 \%)$ \\
Esophagus & $1(3.3 \%)$ & $1(3.4 \%)$ \\
Pancreas & $2(6.7 \%)$ & $1(3.4 \%)$ \\
Melanoma & $1(3.3 \%)$ & $1(3.4 \%)$ \\
Pharynx and mouth & $1(3.3 \%)$ & $2(6.9 \%)$ \\
Uterus & $0(0 \%)$ & $1(3.4 \%)$ \\
Liver and biliary system & $0(0 \%)$ & $1(3.4 \%)$ \\
Colon & $3(10 \%)$ & $3(10.3 \%)$ \\
Lung & $5(16.7 \%)$ & $5(17.2 \%)$ \\
Leukemia & $0(0 \%)$ & $1(3.4 \%)$ \\
Larynx & $3(10 \%)$ & $0(0 \%)$ \\
Urinary bladder/ureter & $2(6.7 \%)$ & $1(3.4 \%)$ \\
Breast & $2(6.7 \%)$ & $2(6.9 \%)$ \\
Lymphoma & $1(3.3 \%)$ & $1(3.4 \%)$ \\
Kidney & $3(10 \%)$ & $3(10.3 \%)$ \\
\hline
\end{tabular}

\subsection{NT-proBNP Plasma Levels Predict a Future Diagnosis of Cancer}

We performed a univariate Cox analysis for all the variables displayed in Table 1, and the result is shown in Table 3. Only age, previous atrial fibrillation, NT-proBNP, and hs-Troponin I plasma levels were associated with the development of cancer in the three first years of follow-up. No variable was associated with a cancer diagnosis beyond that time.

Multivariate Cox regression was performed including variables that showed a $p$ value $<0.20$ at the univariate analysis. We chose this cut-off instead, 0.05 , given that only four variables had a $p$ value $<0.05$, and important information could have been lost if we only included these variables in the multivariate model. NT-proBNP was a strong, independent predictor of developing cancer in the first three years of follow-up, along with the existence of previous atrial fibrillation and the absence of previous heart failure (Table 4). There were no independent predictors of developing cancers beyond three years of follow-up.

Forty patients $(4.4 \%)$ developed heart failure during follow-up in the group not receiving a $\mathrm{CD}, 0(0.0 \%)$ in patients receiving a $\mathrm{CD}$ during the first three years of follow-up, and $2(6.9 \%)$ in patients receiving a CD beyond three years $(p=0.216)$. 
Table 3. Univariate analysis of cancer predictors before and after three years of follow-up.

\begin{tabular}{|c|c|c|c|c|c|c|}
\hline & \multicolumn{3}{|c|}{ Cancer before 3 Years } & \multicolumn{3}{|c|}{ Cancer after 3 Years } \\
\hline & HR & $(95 \%$ CI $)$ & $p$ & HR & $(95 \% \mathrm{CI})$ & $p$ \\
\hline Age & 1.034 & $(1.003,1.065)$ & 0.032 & 1.009 & $(0.978,1.041)$ & 0.583 \\
\hline Sex (woman) & 0.753 & $(0.345,1.644)$ & 0.476 & 0.830 & $(0.366,1.886)$ & 0.657 \\
\hline Diabetes & 0.640 & $(0.245,1.672)$ & 0.363 & 1.257 & $(0.553,2.855)$ & 0.585 \\
\hline Body-mass index & 0.956 & $(0.872,1.049)$ & 0.342 & 0.999 & $(0.915,1.089)$ & 0.976 \\
\hline Past or present smoker & 2.150 & $(0.750,6.160)$ & 0.154 & 1.072 & $(0.455,2.523)$ & 0.874 \\
\hline Present smoker & 0.981 & $(0.342,2.811)$ & 0.971 & 0.602 & $(0.143,2.536)$ & 0.489 \\
\hline Hypertension & 2.183 & $(0.892,5.340)$ & 0.087 & 1.362 & $(0.600,3.092)$ & 0.461 \\
\hline Previous heart failure & 0.262 & $(0.036,1.925)$ & 0.188 & & & \\
\hline Peripheral artery disease & 0.911 & $(0.124,6.689)$ & 0.927 & 0.983 & $(0.133,7.260)$ & 0.987 \\
\hline Cerebrovascular events & & & & 1.354 & $(0.184,9.98)$ & 0.766 \\
\hline Ejection fraction $<40 \%$ & 0.971 & $(0.231,4.085)$ & 0.968 & 1.794 & $(0.540,5.962)$ & 0.340 \\
\hline Present or past atrial fibrillation & 3.144 & $(1.203,8.216)$ & 0.019 & 1.439 & $(0.340,6.082)$ & 0.621 \\
\hline Acetylsalicylic acid & 2.476 & $(0.337,18.18)$ & 0.373 & 0.843 & $(0.254,2.793)$ & 0.780 \\
\hline AntiP2Y12 & 1.156 & $(0.496,2.695)$ & 0.737 & 0.498 & $(0.237,1.048)$ & 0.066 \\
\hline Acenocumarol & 0.667 & $(0.091,4.895)$ & 0.690 & 0.685 & $(0.093,5.042)$ & 0.710 \\
\hline Statins & 0.899 & $(0.214,3.776)$ & 0.885 & 0.902 & $(0.214,3.801)$ & 0.888 \\
\hline Oral antidiabetic drugs & 0.559 & $(0.170,1.844)$ & 0.340 & 1.299 & $(0.526,3.208)$ & 0.570 \\
\hline \multicolumn{7}{|l|}{ Insulin } \\
\hline ACEI & 1.133 & $(0.539,2.381)$ & 0.743 & 0.757 & $(0.360,1.593)$ & 0.463 \\
\hline Angiotensin-receptor blockers & 0.847 & $(0.296,2.428)$ & 0.758 & 1.355 & $(0.549,3.345)$ & 0.509 \\
\hline Aldosterone receptor blockers & 1.031 & $(0.245,4.328)$ & 0.967 & 0.694 & $(0.094,5.109)$ & 0.720 \\
\hline Betablockers & 0.782 & $(0.348,1.758)$ & 0.552 & 0.687 & $(0.310,1.518)$ & 0.353 \\
\hline Diuretic & 1.264 & $(0.542,2.945)$ & 0.588 & 1.319 & $(0.560,3.104)$ & 0.526 \\
\hline \multicolumn{7}{|l|}{ Amiodarone } \\
\hline $\begin{array}{l}\text { Digoxin } \\
\text { LDL }\end{array}$ & 0.994 & $(0.978,1.009)$ & 0.419 & 1.002 & $(0.988,1.017)$ & 0.776 \\
\hline HDL & 1.006 & $(0.974,1.039)$ & 0.710 & 1.010 & $(0.978,1.042)$ & 0.554 \\
\hline Non-HDL & 0.991 & $(0.977,1.004)$ & 0.172 & 1.001 & $(0.990,1.013)$ & 0.819 \\
\hline Triglycerides & 0.994 & $(0.986,1.001)$ & 0.105 & 0.999 & $(0.994,1.004)$ & 0.734 \\
\hline Glucose & 1.001 & $(0.990,1.012)$ & 0.879 & 1.006 & $(0.999,1.013)$ & 0.098 \\
\hline eGFR & 0.991 & $(0.973,1.008)$ & 0.301 & 0.988 & $(0.969,1.008)$ & 0.233 \\
\hline Hs C-Reactive protein & 1.007 & $(0.977,1.038)$ & 0.642 & 0.990 & $(0.937,1.045)$ & 0.709 \\
\hline NT-proBNP ${ }^{*}$ & 1.020 & $(1.004,1.035)$ & 0.012 & 0.987 & $(0.922,1.057)$ & 0.712 \\
\hline MCP-1 & 0.797 & $(0.434,1.463)$ & 0.464 & 0.750 & $(0.365,1.541)$ & 0.434 \\
\hline Galectin-3 & 0.983 & $(0.888,1.087)$ & 0.734 & 0.910 & $(0.796,1.040)$ & 0.165 \\
\hline Hs-Troponin I \# & 1.052 & $(1.005,1.102)$ & 0.029 & 1.516 & $(0.704,3.265)$ & 0.287 \\
\hline Calcidiol & 1.017 & $(0.977,1.058)$ & 0.418 & 0.969 & $(0.920,1.019)$ & 0.222 \\
\hline
\end{tabular}

* Risk change per 100 units of increment in plasma levels. " Risk change per 0.1 units of increment in plasma levels. Variables without results correspond to conditions that were not present in the subgroups described. $\mathrm{HR}=$ hazard ratio; $\mathrm{CI}=$ confidence interval; other abbreviations as for Table 1 . 
Table 4. Multivariate analysis showing the predictors of a cancer diagnosis before 3 years of follow-up.

\begin{tabular}{lll}
\hline & Hazard Ratio $(\mathbf{9 5} \% \mathbf{C I})$ & $p$ Value \\
\hline Variables included in the final model & & \\
\hline NT-proBNP * & $1.036(1.015,1.056)$ & 0.001 \\
\hline Atrial fibrillation & $3.140(1.196,8.243)$ & 0.020 \\
\hline Previous heart failure & $0.067(0.006,0.802)$ & 0.033 \\
\hline Variables not included in the final model & & \\
\hline Age & $1.024(0.992,1.057)$ & 0.140 \\
\hline Past or present smoker & $2.121(0.739,6.090)$ & 0.162 \\
\hline Hypertension & $2.006(0.810,4.968)$ & 0.132 \\
\hline Non-HDL cholesterol & $0.992(0.979,1.005)$ & 0.238 \\
\hline Triglycerides & $0.994(0.987,1.002)$ & 0.149 \\
\hline Hs-Troponin I ${ }^{\#}$ & $1.031(0.981,1.084)$ & 0.227 \\
\hline
\end{tabular}

CI: Confidence Interval; NT-proBNP: N-terminal pro-brain natriuretic peptide. ${ }^{*}$ Risk change per 100 units of increment in plasma levels. ${ }^{\#}$ Risk change per 0.1 units of increment in plasma levels.

\subsection{NT-proBNP Plasma Levels in Different Types of Cancers Diagnosed before Three Years of Follow-Up}

In the subgroup of patients developing cancer in the first 3 years, NT-proBNP levels were $519.8 \pm 706.5 \mathrm{pg} / \mathrm{mL}(\mathrm{N}=15)$ in those with carcinoma and $480.4 \pm 143.0 \mathrm{pg} / \mathrm{mL}$ $(n=11)$ in patients developing adenocarcinoma $(p=0.877)$. Lung and hematologic cancers $(n=6)$ did not have NT-proBNP levels significantly different to other tumors $(n=24)(428.5$ $(152.3,1212.0)$ vs. $257.5(88.0,981.3) \mathrm{pg} / \mathrm{mL}$ respectively; $p=0.402)$.

\section{Discussion}

Patients with CAD have high probabilities of developing tumors, given that the incidence of cancer increases with age [1], tobacco consumption, and some dietary patterns that also promote CAD [2,3]. Thus, predicting the risk of cancer in this population could mean an improvement in the assessment of their global prognosis.

NT-proBNP is mainly used in diagnosing heart failure [15], although it may also predict the development of heart failure and death in patients with cardiovascular disease $[14,16]$. In addition, it has been associated with total death in elderly subjects [17-20].

In 2015, we described for the first time that NT-proBNP is an independent predictor of the appearance of malignancies in patients with CAD [7]. However, we hypothesized that NT-proBNP levels could probably be a marker of subclinical tumors rather than a real predictor of the development of new cancers. To test this hypothesis, we have expanded the sample size and extended the follow-up period of the same series of patients, reporting a total of 59 patients developing cancer instead of the 24 cases reported previously. Then, we divided the patients receiving a new cancer diagnosis during the follow-up into those receiving this diagnosis before and after three years. NT-proBNP was an independent predictor of developing a cancer in the first three years of follow-up, but not later.

The likelihood that concomitant heart failure may have influenced our results is very slim. First, the presence of previous heart failure was very low in the whole sample and significantly lower in patients developing a cancer in the first three years as compared with patients with no cancer at follow-up. Second, a low percentage of our patients developed heart failure during follow-up, without significant differences between the cancer and non-cancer groups. Interestingly, no patient in the group receiving a cancer diagnosis in the first three years developed heart failure during follow-up. Also, variables that may influence NT-proBNP levels, such as age, sex, hypertension, atrial fibrillation, glomerular filtration rate and body-mass index $[16,21,22]$ were included in the multivariate analysis, limiting the possibility that they could have influenced the results. 
Natriuretic peptides are used in patients with cancer mainly as predictors of cardiac toxicity secondary to chemotherapy [23]. However, a potential relationship between plasma levels of these peptides and cancer itself has been suggested, and patients with cancer may have elevated BNP levels in the absence of heart failure [6,24]. In patients $>40$ years of age with previous non-cardiac surgery, NT-proBNP levels $\geq 125 \mathrm{pg} / \mathrm{mL}$ were independently associated with lung cancer after excluding cases with heart failure, CAD, and other conditions known to affect this biomarker [25]. Although natriuretic peptides were shown to be secreted by small-cell lung cancer [5], only $15 \%$ of the cases reported in this previous study, and around $17 \%$ in the present paper, had this type of cancer, suggesting that other tumors could also produce NT-proBNP. In addition, NT-proBNP was an independent predictor of survival in patients with non-Hodgkin lymphoma [26]. Interestingly, NT-proBNP levels were associated with the involvement of two or more extranodal sites, suggesting a potential relationship with the stage of this malignancy. Similarly, increased NT-proBNP plasma levels predict the progression and worse outcome of metastatic renal carcinoma $[27,28]$. In this regard, elevated NT-proBNP levels were reported to be associated with total mortality in patients with cancer and no previous cardiotoxic anticancer therapy who were stable from a cardiovascular point of view [29]. Additionally, NT-proBNP has been found in some series to be of value guiding therapy in heart failure. However, this effect was lost in patients with cancer and other comorbidities, suggesting that NT-proBNP levels may be influenced by this condition [30]. Finally, recent data suggest that cancer biomarkers correlate positively with NT-proBNP plasma levels in patients with heart failure, and even some of them were noninferior to NT-proBNP in predicting all-cause mortality [31]. These findings suggest a bidirectional relationship between biomarkers of cancer and heart failure.

Cancer cells may produce natriuretic peptides. Small-cell lung cancer may secrete both pro-atrial natriuretic peptide and BNP [4,5]. Also, BNP is expressed in normal adrenal glands and in adrenal tumors [32]. NT-proBNP synthesis may be stimulated by several proinflammatory cytokines [33] that, for instance, are expressed in Hodgkin lymphoma [34,35]. Moreover, these cytokines may predict clinical outcome in diffuse large B-cell lymphomas [36-38] and are increased in malignancies at advanced stages [26].

The specific cause of the elevation of natriuretic peptide plasma levels seen in cancer has not yet been elucidated. It has been demonstrated that these peptides decrease the number of several cancer-cell types in vitro through a reduction of DNA synthesis [39] and inhibition of c-Fos and c-Jun protooncogenes [40]. They also diminish the expression of vascular endothelial growth factor and that of its receptor VEGFR2, thus suggesting that these peptides have the potential to control vasculogenesis [41]. One work has shown opposite effects of natriuretic peptides on carcinogenesis depending on their concentrations [42]. Overall, natriuretic peptides seem to decrease the proliferation of cancer cells. Accordingly, they inhibit lung metastases and skin carcinogenesis in animal models [43,44].

Given that most data suggest an anti-cancer effect of natriuretic peptides, it is plausible that their production by cancer cells represents a negative feed-back mechanism trying to control tumor growth. In our study, NT-proBNP was only useful in predicting tumors that were diagnosed in the first three years of follow-up, losing its predictive power beyond this time. This supports the hypothesis that NT-proBNP detects tumors that are present subclinically at the moment of blood extraction and which are not evident using the tools currently available in clinical practice. In that case, NT-proBNP could be useful for the early detection of malignancies, as not all cancers described in this paper have a specific biomarker to aid in diagnosis.

This work has certain limitations: (1) The inverse association between previous heart failure and future cancer must be interpreted with caution, due to the low percentage of patients with heart failure in addition to the limited number of them who developed cancer during follow-up; (2) Given the relatively low number of patients who developed cancer, these findings should be confirmed in other studies, probably including populations without heart failure at baseline; (3) Additionally, given the limited number of patients who 
developed cancer we could not establish whether the predictive effect of NT-proBNP is restricted to some types of cancer or can be applied to any malignancy; (4) Having repeated NT-proBNP levels during follow-up could have aded consistency to the data, but taking more plasma samples from patients was not included in the protocol of the study.

\section{Conclusions}

NT-proBNP might be an independent predictor of malignancies in the intermediateterm follow up in patients with stable CAD. Further prospective studies with larger populations are needed to validate these results.

Author Contributions: Conceptualization, J.T., L.L.B., J.E. and Ó.L.; methodology, J.T., J.A., L.L.B., J.E., I.M.-F. and Ó.L.; formal analysis, J.T., J.M.-M., J.F.-A. and I.M.-F.; patient recruitment: J.T., A.P., Á.A., S.R.-C., N.T., C.C., A.H., C.G.-L., M.L.-C. and J.A.; database cleaning: J.T., J.M.-M., Ó.G.-L., J.F.-A., C.G.-L. and M.L.-C.; laboratory determinations: L.M.B.-C., J.L.M.-V., J.E. and Ó.L.; writingoriginal draft preparation: J.T. and Ó.L.; writing—review and editing: all authors; funding acquisition: J.T. and Ó.L. All authors have read and agreed to the published version of the manuscript.

Funding: This research was funded by Fondo de Investigaciones Sanitarias [PI05/0451, PI14/1567, PI17/01615, P20/00923]; Ministerio de Ciencia e Innovación [RTC2019-006826-1], and the Spanish Society of Arteriosclerosis. RECAVA [RD06/0014/0035]; Instituto de Salud Carlos III FEDER [FJD biobank: RD09/0076/00101].

Institutional Review Board Statement: The study was conducted according to the guidelines of the 1975Declaration of Helsinki and approved by the Ethics Committee of: Fundación Jiménez Díaz, Hospital Fundación Alcorcón, Hospital de Fuenlabrada, Hospital Universitario Puerta de HierroMajadahonda, and Hospital Universitario de Móstoles.

Informed Consent Statement: Informed consent was obtained from all subjects involved in the study.

Data Availability Statement: Data are available on request to the corresponding author.

Acknowledgments: Oliver Shaw (Quirón, Spain) assisted us in editing this work.

Conflicts of Interest: The authors declare no conflict of interest. The funders had no role in the design of the study; in the collection, analyses, or interpretation of data; in the writing of the manuscript, or in the decision to publish the results.

\section{References}

1. DePinho, R.A. The age of cancer. Nature 2000, 408, 248-254. [CrossRef] [PubMed]

2. Doll, R.; Peto, R. The causes of cancer: Quantitative estimates of avoidable risks of cancer in the United States today. J. Natl. Cancer Inst. 1981, 66, 1191-1308. [CrossRef]

3. Willett, W.C. Diet and cancer. Oncologist 2000, 5, 393-404. [CrossRef]

4. $\mathrm{Wu}, \mathrm{F}$; $\mathrm{Wu}, \mathrm{Q}$. Corin-mediated processing of pro-atrial natriuretic peptide in human small cell lung cancer cells. Cancer Res. 2003, 63, 8318-8322.

5. Ohsaki, Y.; Gross, A.J.; Le, P.T.; Oie, H.; Johnson, B. Human small cell lung cancer cells produce brain natriuretic peptide. Oncology 1999, 56, 155-159. [CrossRef]

6. Popat, J.; Rivero, A.; Pratap, P.; Guglin, M. What is causing extremely elevated amino terminal brain natriuretic peptide in cancer patients? Congest. Heart Fail. 2013, 19, 143-148. [CrossRef]

7. Tuñón, J.; Higueras, J.; Tarín, N.; Cristóbal, C.; Lorenzo, O.; Blanco-Colio, L.; Martín-Ventura, J.L.; Huelmos, A.; Alonso, J.J.; Aceña, Á.; et al. N-Terminal Pro-Brain Natriuretic Peptide Is Associated with a Future Diagnosis of Cancer in Patients with Coronary Artery Disease. PLoS ONE 2015, 10, e0126741. [CrossRef]

8. Gu, L.; Okada, Y.; Clinton, S.K.; Gerard, C.; Sukhova, G.K.; Libby, P.; Rollins, B.J. Absence of monocyte chemoattractant protein-1 reduces atherosclerosis in low density lipoprotein receptor-deficient mice. Mol. Cell. 1998, 2, 275-281. [CrossRef]

9. Gosling, J.; Slaymaker, S.; Gu, L.; Tseng, S.; Zlot, C.H.; Young, S.; Rollins, B.J.; Charo, I.F. MCP-1 deficiency reduces susceptibility to atherosclerosis in mice that overexpress human apolipoprotein B. J. Clin. Investig. 1999, 103, 773-778. [CrossRef] [PubMed]

10. Lok, D.J.A.; Van Der Meer, P.; De La Porte, P.W.B.-A.; Lipsic, E.; Van Wijngaarden, J.; Hillege, H.L.; Van Veldhuisen, D.J. Prognostic value of galectin-3, a novel marker of fibrosis, in patients with chronic heart failure: Data from the DEAL-HF study. Clin. Res. Cardiol. 2010, 99, 323-328. [CrossRef] [PubMed]

11. Dumic, J.; Dabelic, S.; Flogel, M. Galectin-3: An open-ended story. Biochim. Biophys. Acta 2006, 1760, 616-635. [CrossRef] [PubMed] 
12. Omland, T.; Pfeffer, M.A.; Solomon, S.D.; de Lemos, J.A.; Røsjø, H.; Benth, J.; Maggioni, A.P.; Domanski, M.J.; Rouleau, J.L.; Sabatine, M.S.; et al. Prognostic value of cardiac troponin I measured with a highly sensitive assay in patients with stable coronary artery disease. J. Am. Coll. Cardiol. 2013, 61, 1240-1249. [CrossRef]

13. McCullough, M.L.; Zoltick, E.S.; Weinstein, S.J.; Fedirko, V.; Wang, M.; Cook, N.R.; Eliassen, A.H.; Zeleniuch-Jacquotte, A.; Agnoli, C.; Albanes, D.; et al. Circulating Vitamin D and Colorectal Cancer Risk: An International Pooling Project of 17 Cohorts. J. Natl. Cancer Inst. 2018, 111, 158-169. [CrossRef] [PubMed]

14. Tuñón, J.; Blanco-Colio, L.M.; Cristóbal, C.; Tarín-Vicente, N.; Higueras, J.; Huelmos, A.; Alonso, J.J.; Egido, J.; Asensio, D.; Lorenzo, O.; et al. Usefulness of a combination of monocyte chemoattractant protein-1, galectin-3, and N-terminal probrain natriuretic peptide to predict cardiovascular events in patients with coronary artery disease. Am. J. Cardiol. 2014, 113, 434-440. [CrossRef]

15. Maisel, A.S.; Krishnaswamy, P.; Nowak, R.M.; Mccord, J.; Hollander, J.; Duc, P.; Omland, T.; Storrow, A.B.; Abraham, W.T.; Wu, A.H.; et al. Breathing Not Properly Multinational Study I. Rapid measurement of B-type natriuretic peptide in the emergency diagnosis of heart failure. N. Engl. J. Med. 2002, 347, 161-167. [CrossRef]

16. Daniels, L.B.; Maisel, A.S. Natriuretic peptides. J. Am. Coll. Cardiol. 2007, 50, 2357-2368. [CrossRef]

17. Vaes, B.; De Ruijter, W.; Degryse, J.; Westendorp, R.G.J.; Gussekloo, J. Clinical relevance of a raised plasma N-terminal pro-brain natriuretic peptide level in a population-based cohort of nonagenarians. J. Am. Geriatr. Soc. 2009, 57, 823-829. [CrossRef] [PubMed]

18. Daniels, L.B.; Laughlin, G.A.; Clopton, P.; Maisel, A.S.; Barrett-Connor, E. Minimally elevated cardiac troponin T and elevated N-terminal pro-B-type natriuretic peptide predict mortality in older adults: Results from the Rancho Bernardo Study. J. Am. Coll. Cardiol. 2008, 52, 450-459. [CrossRef]

19. Eggers, K.M.; Venge, P.; Lind, L. Prognostic usefulness of the change in N-terminal pro B-type natriuretic peptide levels to predict mortality in a single community cohort aged $>/=70$ years. Am. J. Cardiol. 2013, 111, 131-136. [CrossRef]

20. Barents, M.; Hillege, H.H.; Van Der Horst, I.C.; De Boer, R.A.; Koster, J.; Muskiet, F.A.; De Jongste, M.J. BNP and NT-proBNP, predictors of 1-year mortality in nursing home residents. J. Am. Med. Dir. Assoc. 2008, 9, 580-585. [CrossRef]

21. Soualmia, H.; Ayadi, I.; Omar, S.; Feki, M.; Drissa, H.; Mebazaa, A.; Kaabachi, N. Atrial natriuretic peptide and brain natriuretic peptide release in human essential hypertension. Clin. Lab. 2009, 55, 120-127. [PubMed]

22. Knudsen, C.W.; Omland, T.; Clopton, P.; Westheim, A.; Wu, A.H.; Duc, P.; McCord, J.; Nowak, R.M.; Hollander, J.; Storrow, A.B.; et al. Impact of atrial fibrillation on the diagnostic performance of B-type natriuretic peptide concentration in dyspneic patients: An analysis from the breathing not properly multinational study. J. Am. Coll. Cardiol. 2005, 46, 838-844. [CrossRef] [PubMed]

23. Sandri, M.T.; Salvatici, M.; Cardinale, D.; Zorzino, L.; Passerini, R.; Lentati, P.; Leon, M.; Civelli, M.; Martinelli, G.; Cipolla, C.M. $\mathrm{N}$-terminal pro-B-type natriuretic peptide after high-dose chemotherapy: A marker predictive of cardiac dysfunction? Clin. Chem. 2005, 51, 1405-1410. [CrossRef] [PubMed]

24. Burjonroppa, S.C.; Tong, A.T.; Xiao, L.-C.; Johnson, M.M.; Yusuf, S.W.; Lenihan, D.J. Cancer patients with markedly elevated B-type natriuretic peptide may not have volume overload. Am. J. Clin. Oncol. 2007, 30, 287-293. [CrossRef]

25. Aujollet, N.; Meyer, M.; Cailliod, R.; Combier, F.; Coignet, Y.; Campard, S.; Facy, O.; Bernard, A.; Girard, C. High N-terminal pro-B-type natriuretic peptide: A biomarker of lung cancer? Clin. Lung Cancer 2010, 11, 341-345. [CrossRef]

26. Gimeno, E.; Gómez, M.; González, J.R.; Comín, J.; Alvarez-Larrán, A.; Sánchez-González, B.; Molina, L.; Domingo-Domenech, E.; Garcia-Pallarols, F.; Pedro, C.; et al. NT-proBNP: A cardiac biomarker to assess prognosis in non-Hodgkin lymphoma. Leuk. Res. 2011, 35, 715-720. [CrossRef] [PubMed]

27. Papazisis, K.T.; Kontovinis, L.F.; Papandreou, C.N.; Kouvatseas, G.; Lafaras, C.; Antonakis, E.; Christopoulou, M.; Andreadis, C.; Mouratidou, D.; Kortsaris, A.H. Brain natriuretic peptide precursor (NT-pro-BNP) levels predict for clinical benefit to sunitinib treatment in patients with metastatic renal cell carcinoma. BMC Cancer 2010, 10, 489. [CrossRef] [PubMed]

28. Kamai, T.; Tokura, Y.; Uematsu, T.; Sakamoto, K.; Suzuki, I.; Takei, K.; Narimatsu, T.; Kambara, T.; Yuki, H.; Betsunoh, H.; et al. Elevated serum levels of cardiovascular biomarkers are associated with progression of renal cancer. Open Heart 2018, 5 , e000666. [CrossRef]

29. Pavo, N.; Raderer, M.; Hülsmann, M.; Neuhold, S.; Adlbrecht, C.; Strunk, G.; Goliasch, G.; Gisslinger, H.; Steger, G.G.; Hejna, M.; et al. Cardiovascular biomarkers in patients with cancer and their association with all-cause mortality. Heart 2015, 101, 1874-1880. [CrossRef]

30. Brunner-La Rocca, H.P.; Eurlings, L.; Richards, A.M.; Januzzi, J.L.; Pfisterer, M.E.; Dahlström, U.; Pinto, Y.M.; Karlström, P.; Erntell, H.; Berger, R.; et al. Which heart failure patients profit from natriuretic peptide guided therapy? A meta-analysis from individual patient data of randomized trials. Eur. Heart J. 2015, 17, 1252-1261. [CrossRef]

31. Shi, C.; Van Der Wal, H.H.; Silljé, H.H.W.; Dokter, M.M.; Berg, F.V.D.; Huizinga, L.; Vriesema, M.; Post, J.; Anker, S.D.; Cleland, J.G.; et al. Tumour biomarkers: Association with heart failure outcomes. J. Intern. Med. 2020, 288, 207-218. [CrossRef] [PubMed]

32. Totsune, K.; Takahashi, K.; Murakami, O.; Satoh, F.; Sone, M.; Ohneda, M.; Miura, Y.; Mouri, T. Immunoreactive brain natriuretic peptide in human adrenal glands and adrenal tumors. Eur. J. Endocrinol. 1996, 135, 352-356. [CrossRef] [PubMed]

33. Kuwahara, K.; Nakao, K. Regulation and significance of atrial and brain natriuretic peptides as cardiac hormones. Endocr. J. 2010, 57, 555-565. [CrossRef] 
34. Skinnider, B.F.; Elia, A.J.; Gascoyne, R.D.; Patterson, B.; Trumper, L.; Kapp, U.; Mak, T.W. Signal transducer and activator of transcription 6 is frequently activated in Hodgkin and Reed-Sternberg cells of Hodgkin lymphoma. Blood 2002, 99, 618-626. [CrossRef]

35. Biggar, R.J.; Johansen, J.S.; Smedby, K.E.; Rostgaard, K.; Chang, E.T.; Adami, H.-O.; Glimelius, B.; Molin, D.; Hamilton-Dutoit, S.; Melbye, M.; et al. Serum YKL-40 and interleukin 6 levels in Hodgkin lymphoma. Clin. Cancer Res. 2008, 14, 6974-6978. [CrossRef]

36. Niitsu, N.; Okamato, M.; Nakamine, H.; Yoshino, T.; Tamaru, J.; Nakamura, S.; Higashihara, M.; Hirano, M. Simultaneous elevation of the serum concentrations of vascular endothelial growth factor and interleukin- 6 as independent predictors of prognosis in aggressive non-Hodgkin's lymphoma. Eur. J. Haematol. 2002, 68, 91-100. [CrossRef]

37. Seymour, J.F.; Talpaz, M.; Cabanillas, F.; Wetzler, M.; Kurzrock, R. Serum interleukin-6 levels correlate with prognosis in diffuse large-cell lymphoma. J. Clin. Oncol. 1995, 13, 575-582. [CrossRef] [PubMed]

38. Pedersen, L.M.; Jürgensen, G.W.; Johnsen, H.E. Serum levels of inflammatory cytokines at diagnosis correlate to the bcl-6 and CD10 defined germinal centre (GC) phenotype and bcl-2 expression in patients with diffuse large B-cell lymphoma. Br. J. Haematol. 2005, 128, 813-819. [CrossRef]

39. Vesely, B.A.; Song, S.; Sanchez-Ramos, J.; Fitz, S.R.; Alli, A.A.; Solivan, S.M.; Gower, W.R.; Vesely, D.L. Five cardiac hormones decrease the number of human small-cell lung cancer cells. Eur. J. Clin. Investig. 2005, 35, 388-398. [CrossRef]

40. Manimala, N.J.; Frost, C.D.; Lane, M.L.; Higuera, M.; Beg, R.; Vesely, D.L. Cardiac hormones target nuclear oncogenes c-Fos and c-Jun in carcinoma cells. Eur. J. Clin. Investig. 2013, 43, 1156-1162. [CrossRef]

41. Nguyen, J.P.; Frost, C.D.; Lane, M.L.; Iv, W.P.S.; Skelton, M.; Vesely, D.L. Novel dual inhibitors of vascular endothelial growth factor and VEGFR2 receptor. Eur. J. Clin. Investig. 2012, 42, 1061-1067. [CrossRef] [PubMed]

42. Zhang, J.; Zhao, Z.; Zu, C.; Hu, H.; Shen, H.; Zhang, M.; Wang, J. Atrial natriuretic peptide modulates the proliferation of human gastric cancer cells via KCNQ1 expression. Oncol. Lett. 2013, 6, 407-414. [CrossRef] [PubMed]

43. Zhang, J.; Zhao, Z.; Wang, J. Natriuretic peptide receptor A as a novel target for cancer. World J. Surg. Oncol. 2014, 12, 174. [CrossRef] [PubMed]

44. Subramanian, V.; Vellaichamy, E. Atrial natriuretic peptide (ANP) inhibits DMBA/croton oil induced skin tumor growth by modulating NF-kappaB, MMPs, and infiltrating mast cells in swiss albino mice. Eur. J. Pharmacol. 2014, 740, 388-397. [CrossRef] 